\title{
The Color of Childhood: The Role of the Child/ Human Binary in the Production of Anti-Black Racism
}

Journal of Black Studies 2018, Vol. 49(4) 307-329

(C) The Author(s) 2018

Reprints and permissions: sagepub.com/journalsPermissions.nav DOI: $10.1177 / 0021934718760769$ journals.sagepub.com/home/jbs

(S)AGE

\section{Toby Rollo'}

\begin{abstract}
The binary between the figure of the child and the fully human being is invoked with regularity in analyses of race, yet its centrality to the conception of race has never been fully explored. For most commentators, the figure of the child operates as a metaphoric or rhetorical trope, a non-essential strategic tool in the perpetuation of White supremacy. As I show in the following, the child/ human binary does not present a contingent or merely rhetorical construction but, rather, a central feature of racialization. Where Black peoples are situated as objects of violence it is often precisely because Blackness has been identified with childhood and childhood is historically identified as the archetypal site of naturalized violence and servitude. I proceed by offering a historical account of how Black peoples came to inherit the subordination and dehumanization of European childhood and how White youth were subsequently spared through their partial categorization as adults.
\end{abstract}

\section{Keywords}

racialization, anti-Blackness, colonialism, slavery, childhood, child races

\footnotetext{
IThe University of British Columbia, Vancouver, Canada

\section{Corresponding Author:}

Toby Rollo, The University of British Columbia, 1866 Main Mall-C425, Vancouver, British Columbia, Canada V6T IZI.

Email: rollotob@mail.ubc.ca
} 
Take up the White Man's burden, Send forth the best ye breed

Go bind your sons to exile, to serve your captives' need;

To wait in heavy harness, On fluttered folk and wild-

Your new-caught, sullen peoples, Half-devil and half-child.

—Rudyard Kipling (1899, The White Man's Burden)

\section{Introduction}

In his infamous ode to American imperialism, The White Man's Burden, Rudyard Kipling depicts people of color as degraded, comparing them with both devil and child. This close coupling of Biblical evil and childhood in reference to people of color reflected colonial Europe's self-assumed obligation to tutor the sinful and ignorant non-European subjects of empire through force. This sense of parental burden — one that obligates White authorities to discipline racialized groups-persists today as Black peoples (and Black children in particular) are disproportionally exposed to violence in education, policing, and carceral systems. This legacy of anti-Black racism and an ongoing denial of basic humanity reflects the "afterlife of slavery" that continually situates Black peoples as objects of fetish and force (Hartman \& Wilderson, 2003; Sexton, 2010, 2015). It perpetuates a denial of Black humanity that Orlando Patterson (1982) identifies as the "social death" of enslaved peoples and which plays a foundational yet chronically neglected role in contemporary conceptions of boundaries to both humanity and political order. Modern freedom was initially conceived of as the freedom of European peoples posited in opposition to Black slavery, as Saidiya Hartman and Frank Wilderson (2003) have observed, which meant that the slave became "the foundation of the national order," while also occupying "the position of the unthought" (p. 185). If we are to fully grasp these historical conditions, as Hortense Spillers (1987) has urged us to do, attention must be paid to the modern condition of Blackness and social death as the foundational "zero degree of social conceptualization" (p. 67). This positional problem is especially acute for youth, since, as writers like Audre Lorde (1984) have observed, Black children are often preoccupied with survival within a fundamentally anti-Black culture, and therefore "never allowed to be children" (p. 171).

It is common for theorists of race and colonialism to interpret violence against racialized youth as a case of children being treated like adults and excluded from the protective innocence of childhood. In this article, I show that anti-Black racism is derived from the naturalized position of subordination and violence that children have traditionally occupied in European social and political orders. Black peoples, especially youth, are exposed to violence 
precisely because they are viewed as children. Whereas the figure of the child is usually thought to operate as a mere metaphor, rhetorical trope, or otherwise strategic tool in the infantilization of Black peoples, I contend, that the historical binary opposition between the fully human adult and the subhuman child was an essential framework in early-modern philosophical and scientific constructions of Whiteness and White superiority.

An awareness of this association between degraded childhood and Blackness is often intimated in the works of Black writers. Hartman (1997), for instance, relate how the "spectre of powerful and childish men" terrified Whites, and especially White men, in the American South (p. 162). Patterson (1982) reveals how the ideal slave was a conceived of as a "degraded manchild" (p. 96). More recently, Jared Sexton invokes Lewis Gordon's formulation of racialized modernity: "in a world structured by the twin axioms of white superiority and black inferiority, of white existence and black nonexistence, a world distracted by negative categorical imperative- 'above all, don't be black"' (Sexton, 2011, p. 27). Here, Sexton draws from Gordon's (1997) account, put forth in his book, Her Majesty's Other Children: Sketches of Racism From a Neocolonial Age. The "other children" to whom Gordon's title refers are those designated as "anonymous, invisible, Other, and even below-Other" (p. 5). The idea of the child as an object without status or legitimate claims to status was central to the practice of racial slavery in America, where children of slave women were deemed to inherit the condition of their mothers, guaranteeing a slave population in perpetuity (see Hartman, 2016; Spillers, 1987). This norm followed directly from the European practice of veiwing the child as possessing no ontological status, no fundamental moral standing other than that which is conferred by adults. In the congenital vision of slavery and naturalized violence, then, we see echoes of widespread preChristian practices of infanticide, the Roman doctrine of paterfamilias, which gave fathers absolute power over the life, death, and reproduction of free children, as well as the doctrine of partus sequitur ventrem, which held that the children of slave women were also slaves. Adults seized the exclusive prerogative to construct the norms and laws of kinship and enslavement that determined the fate of the child, a figure who was transformed, consequently, into no more than a passive object of various competing adult imaginaries and epistemologies. Thus, by the medieval period, it was deemed technically illegal to murder children without cause (disobedience was often accepted as just cause), yet it was permissible to beat or even torture children. This same empty technical protection against murder would be extended to slaves in America (Hartman, 1997, p. 91) with statutes like the 1669 "Casual Killing Act" decreeing that a slave could only justifiably be killed for active disobedience. 
Western traditions that positioned children as fungible bodies provided a template upon which chattel slavery was actively constructed. As I show in the following, the idea of the sub-human child is an antecedent structuring principle of race. Where Black peoples are situated as objects of violence, it is often precisely because Blackness is identified with a state of childhood and because the child is already understood as a perennial archetype of naturalized violence, servitude, and criminality (see Duane, 2017). From this perspective, the claim that Black youth are denied protective childhood appears to draw from an ahistorical account, for in no era has childhood proven to be a genuine site of security or safety. Black youth (and Black peoples more generally) are thus consigned to the status of child and its corollary denials of status, claims, and rights. To the extent that White youth are spared, I argue, it is because they have been removed (if only partially) from the category of childhood and proffered some of the privileges normally reserved for adults, namely, the juridical presumption of legal innocence.

I conclude that challenging anti-Black racism requires an interrogation of the anti-child ageism at its core. I refer to this paradigm of childhood viewed as a site of naturalized discipline, violence, and criminality as misopedy, which, like its cognate term misogyny, denotes both antipathy toward the constructed group as well as fetishization and objectification of that group. Addressing the modern racial order involves the deconstruction not only of the surface discourses of biological racialization but also the underlying misopedic grammar of race itself. It is vital to move below surface level discourses of race to its core structures because hierarchical divisions of humanity are reaffirmed rather than dissolved when adult capacities for reason, speech, and claim-making are asserted as the grounds of equality and inclusion into the family of humanity. Put another way, the cultural structure of racialization - of civlized and uncivilized - is not challenged but preserved when the equality of marginalized peoples is predicated on their possession of mature intelligence and self-control and, therefore, their complete and fully realized human faculties.

\section{Origins of Misopedic Racialization}

Racialization is a modality of civilizational domination and exclusion. Sylvia Wynter (2003) locates the origins of this modality in ancient Greek practices of ethno-astronomy where "the moral/political laws of the Greek polis had been projected upon the physical cosmos" (p. 271). The Greeks, like most intellectual cultures seeking to rationalize customary practices of slavery and patriarchy, mapped their parochial "master governing codes on the heavens" in order to imbue "their specific criterion of being human" with the authority of cosmological order and certainty (p. 272). Subsequent Judeo-Christian cosmologies would inherit this 
vision of humanity as divided according to a divine hierarchy and/or Manichean binary, a principle that was preserved for millennia leading up to the emergence of scientific racism in the 19th century. The initial effect on medieval European culture was to "absolutize the central order-organizing principle and genre-of-thehuman distinction at the level of the sociopolitical order, between the non-dependent masters who were Greek born citizens and their totally dependent slaves classified as barbarian Others" (p. 272). As Western history unfolded, this naturalized order of masters and barbarian slaves, predicated on the barbarian's "coloniality of being," positioned White European Man over and against "its subjugated Human Others (i.e., Indians and Negroes)," and in doing so established "the foundational basis of modernity" (Wynter, 2003). Black peoples came to be designated as "the ostensible missing link between rational humans and irrational animals" (p. 266).

The figure of the barbarian Other is a conventional starting point for analysis of racialized slavery, yet it is not the most central or most prevalent subhuman figure in Greek or medieval Christian thought, nor is it the most influential opposition to inform modern Enlightenment thinking. The barbarian Other is not the conceptual precedent of modern racialization. Indeed, a key step in understanding the development of racialized modernity is overlooked in our focus on the foreign barbarian, for the accident of being foreign only contingently excludes one from the ideal of substantive human equality and full political agency. The obvious contingency of being born foreign gave rise to over 2000 years of debate over the enslavement of foreigners. By contrast, the subordination of children was considered indelibly natural, necessary, and morally incontrovertible. The unambiguous state of childhood inferiority positioned the child as a central model of Othering. The baby, unlike the barbarian, is situated as sub-human based on their undeniable lack of speech and reason $(\log o s)$, meaning they are precluded from contributing to the reflective philosophical self-understanding of humanity as full humans by definition rather than by accident.

In classical Greece, children were commonly bought, sold, or loaned out as slaves, primarily for labor and sexual exploitation (Laes, 2006, Chapter 5). A prevailing norm of childhood fungibility continued into the Roman era where it was legally formalized in the principle of paterfamilias, a juridical interpretation of the child's natural dependency on, and natural subordination to, a father (Cooper, 2007, p. 111). With few legal exceptions, the paterfamilia held absolute power (potestas) over his children and was therefore entitled to organize his child's marriage and reproductive life, to sell them into slavery or, in some circumstances, to kill them (Mousourakis, 2012, pp. 88-91). Children usually remained under the jurisdiction of the paterfamilia into adulthood and gained freedom only upon the father's death or by undergoing the onerous legal process of emancipation, a procedure similar to manumission of slaves (Gardner, 1998, pp. 79-80). 
For early Christian thinkers, Greco-Roman legal understandings of childhood informed a revolutionary new vision of social order and historical change. Christian society, while heavily stratified, was held together by its conceptual foundation, the "great chain of being," within which everyone from the King to the lowliest peasant occupied a divinely ordained place in a formal hierarchy. This theological ordering of society mapped directly onto the hierarchical familial relationship imported from Greco-Roman practices, with God serving as the paterfamilia or dominus over his children, slaves, and worldly estate. In his Institutiones Divinae (4.3.14-15), Lactantius, an advisor to Constantine, the first Christian emperor of Rome, asserted that the authority of God can be extrapolated from the legal framework of Roman domestic authority expressed in civil law doctrine (iuris ciuilis ratio).

Children remained feral animals in the absence of strict education. As one writer summarized the prevailing Christian view, "A child was not believed to be truly human simply by birthright; he was a creature in search of humanity - unpredictable, capable of animal indolence, selfishness, and savagery, traits that would dominate his adult life if they were not controlled in childhood" (Ozment, 1983, pp. 138-139). Parents had a moral obligation to educate the young, even through force. Leading up to the 17th century, however, this strictly theological vision of spiritual progress through education in faith would be displaced by the Enlightenment vision of civilizational progress through education in reason. Where faith and tradition had once grounded social and political hierarchies, early Enlightenment thinkers advocated for institutions based on principles of rational consent (see Brewer, 2007). One of the effects of rooting political agency and legitimate political authority in the capacity for consent was that children (and by extension, those categorized as children) were precluded from participating in political and economic life as full agents. In this respect, the new "Age of Reason" was conceptualized in explicit opposition to the figure of the child. The explosion of ideas related to modern democracy, collective sovereignty, and political authority were predicated on a public sphere of equal able-bodied men, often in direct and explicit contradistinction to a private domestic sphere of non-consensual authority and violence whose only permanent occupants would prove to be children.

\section{The Child Races}

To establish and buttress the practice of African slavery, colonial societies relied initially on Christian notions of a right of conquest but shifted very quickly to norms of authority and subordination derived from the apolitical domain of the household or domestic sphere. Anne McClintock (1995) describes the latter process succinctly: "Because the subordination of woman to man and child to adult were deemed natural facts, other forms of social 
hierarchy could be depicted in familiar terms to guarantee social difference as a category of nature" (p. 45). The familiar misopedic discourse of childhood inferiority served as a ready-made scaffold upon which the facades of race, cultural hierarchies, and civilizational progress could be easily fixed in the rationalizing of the slave trade. Because classical justifications of slavery based on rights of conquest ("to the victor go the spoils") conflicted with the universal spirit of liberal democratic ideals, they eventually gave way to justifications rooted in paternal duties to exercise authority over the world's immature "child races." Colonial philosophers like John Stuart Mill $(1859 / 1989)$ supplied elaborate rationales for empire and colonialism, asserting in On Liberty, for example, that children and savage peoples (who are also considered children) have no inherent rights to bodily integrity or freedom from violence (p. 13).

The emergence of scientific racism in the 19th century provided a veneer of scholarly legitimacy to the idea that darker skin color and other aspects of non-European physiology and phenotype were indicators of sub-human childhood. Within the emerging logic of racialization, physiological markers of youth such as size, proportion, and coordination, which rendered children hyper-visible and permitted their immediate recognition as fungible bodies, began to shift to skin color and other physically coded markers. The crucial difference between the subordination of European children and Black peoples was, of course, that these new corporeal markers of childhood had permanence throughout the life of the individual; there would be no emancipation from the new color of childhood and no reprieve from the objectifying gaze of the adult as master. To their discredit, the newly emerging academic social sciences were wholly uncritical of orthodox biological notions of race and initiated their disciplinary studies by providing enthusiastic support for the alleged perpetual childhood of non-Europeans.

By the end of the 19th century, Black peoples were understood explicitly by anthropologists, physicians, and biologists as one of the archetypal "child races" (Jacobs, 2009, pp. 74-76). Writing in this era, The Rev. William C. Holden (1855) provides a typical example of the categorization of Black peoples (referred to as "Kaffir" by White South African society) as perpetual children.

The Kaffirs must be treated like children. If a man has a large family, and leaves them without restraint or control, his children become a plague to himself and a scourge to the community. The Kaffirs are children of a larger growth, and must be treated accordingly, children in knowledge, ignorant of the relationships of civilized society, and strangers to many of the motives which influence the conduct of the white man. (p. 215)

Those working in politics and philosophy made extensive use of scientific and social scientific discourses of racialization to construct the idea of a 
"white man's burden" and a duty to educate these child races. Nineteenthcentury American politician William Drayton (1836), for example, expressed the conventional view of his day: "the negro is a child in his nature, and the white man is to him as a father" (p. 304). The English philosopher, William Winwood Reade (1872), affirmed that it was no mere analogy: "Children are ruled and schooled by force, and it is not an empty metaphor to say that savages are children" (p. 506). In South Africa, Cecil Rhodes infamously declared to Parliament that "The native is to be treated as a child and denied the franchise" (quoted in Magubane, 1996, p. 108). In the American context, George T. Winston (1901), then President of what is now North Carolina State University, argued that blacks in America were doomed to childhood:

The Negro is a child race. If isolated from the world and left to himself, he might slowly grow to manhood along separate lines and develop a Negro civilization; but in the United States such isolation and such development are quite impossible. (p. 118)

Black peoples were positioned as sub-human-children and therefor suitable only for servitude and labor under the direction of a guardian:

The negro race is a child race and must remain in tutelage for years to come; in tutelage not of colleges and universities, but of industrial schools, of skilled and efficient labor, of character building by honest work and honest dealing, of good habits and good manners, of respect for elders and superiors, of daily employment on the farm, the household, the shop, the forest, the factory and the mine. (Winston, 1901)

Indeed, Winston lamented that it would prove "a cruelty greater than slavery to leave this helpless race, this child race, to work out its own salvation in fierce and hostile competition with the strongest and best developed race on the globe" (p. 116). To that end, Albert Schweitzer (1931) summarized two centuries of European misopedic thought: "The Negro is a child, and with children nothing can be done without the use of authority. We must, therefore, so arrange the circumstances of daily life that my natural authority can find expression" (p. 99). Absent the guardianship and natural parental authority of White society, the inclination of the child races, as it is for all children, was deemed to be toward idleness, disobedience, and lawlessness. The notion of the inherent criminality of childhood had a long history. In the American colonies, the disobedience of children was identified as a significant social problem, to which the Puritan colony of Massachusetts Bay responded with the Stubborn Child Act of 1646, declaring that the penalty for persistent disobedience would be execution. Two centuries later, physician and "father 
of criminology," Cesare Lombroso (1895) proposed the idea of congenital criminality following the observation that "in the child up to a certain age are manifested the saddest tendencies of the criminal man" (p. 53). Without discipline to bring instincts into abeyance, the natural sinfulness and criminality of the child would go unchecked as "children manifest a great many of the impulses we have observed in criminals; anger, a spirit of revenge, idleness, volubility and lack of affection" (p. 134). The American historian, Francis Parkman (1851/1994) argued that uncivilized races (in this case, Indigenous peoples) were to be feared precisely because they were lawless children: "Barbarism is to civilization what childhood is to maturity; and all savages, whatever may be their country, their color, or their lineage, are prone to treachery and deceit" (p. 166). A century later, another American defender of scientific racism and slavery expressed what was considered common sense in his time: "The average Negro is a child in every essential element of character, exhibiting those characteristics that indicate a tendency to lawless impulse and weak inhibition" (McCord, 1914, p. 108). In their categorization as children, Black peoples had also been cast as criminally deviant. Ironically, the designation of Black men as children meant that they were veiwed as inherently desirous animals that "could not control those desires" because they "lacked the 'moral sense' that came with maturity" (Robertson, 1992, p. 214).

The physical maturity of adult Black men combined with the criminality of child races remains a persistent source of cultural fear and anxiety for White society. The first President of the American Psychological Association, Stanley Hall (1904), articulated these popular confusions, writing that "most savages in most respects are children, or, because of sexual maturity, more properly, adolescents of adult size" (p. 649). White society was not prepared for the ramifications of the idea of physically mature children. As mentioned in the introduction, the "spectre of powerful and childish men" was terrifying for Whites, especially White men, in the South (Hartman 1997, p. 162). By way of illustration, consider the following remarks on the effectiveness of disciplinary punishment, offered by John H. Van Evrie (1853), a physician, publisher, and perhaps the most prolific propagandist of scientific racism and slavery in American history. Van Evrie assures his readers that

The negro is a child forever, a child in many respects in his physical as well as his mental nature, and the flogging of the negro of fifty does not differ much, if any, from the flogging of a child of ten. (p. 122)

Today, we find echoes of this terror in the testimony of police who claim to have been intimidated by the immense size and strength of Black children, against whom they felt compelled to use deadly force in self-defense. 
Black commuities have always possessed their own visions of childhood. Likewise, black thinkers have resisted infantilization in different ways. Frederick Douglass famously observed that to be a child in his time was to exist as a laboring thing (Woodhouse, 2008, Chapter 3), but whereas White children were permitted to mature out of servitude, Black children enjoyed no such future. At the same time, the vision of human beings as equal children under God irrespective of race held significant rhetorical force for some Black religious thinkers (see Bunge, Frethiem, \& Gaventa, 2008). By the 1960 s, writers and activists had begun deconstructing the misopedic grammar of White supremacy: "He has been treated as member of a 'child' race . . Since, as it is said, Negroes are a childlike race, they have been shunted from the main currents of American life" (Frazier, 1962, p. 70).

Frantz Fanon was among the first modern Black writers to articulate the place of Blackness in the grammar of coloniality, not merely as shunted, but positioned in what he called an "ontological misfortune" that presents colonial violence as a moral imperative for both colonized and colonizer. Fanon (2008b) observed that colonialism invites the Black subject to understand themselves as a child for whom the colonizer stands as "a mother who constantly prevents her basically perverse child from committing suicide or giving free rein to its malevolent instincts," a colonial mother who "is protecting the child from itself, from its ego, its physiology, its biology, and its ontological misfortune." (p. 149). Fanon was also among the first to discuss how the speech of Black people is associated not with reason but with the aimless talk of the child. Black peoples, writes Fanon, are viewed as a "group of children calling and shouting for the sake of calling and shouting - children in the midst of play," and thus, in the misopedic structure of White supremacy, "the black man is just a child" (pp. 26-27). As a member of a child race, a Black person is subject to both the abuses and the fetishization that render their bodies and their agency fungible. Sometimes an object of hatred and fear, at other times Black peoples are fetishized as laughing and playing children who serve as an endearing reminder to White society of a simpler, pre-modern time (p. 132).

Following Fanon, Orlando Patterson (1982) unpacked the condition of slavery to reveal its foundations in "social death" and "natal alienation," referring to the slave's loss of ties to previous and future generations and the inability to make claims of birth (p. 5). Patterson's definition of slavery has been critiqued as too restrictive and arbitrary given that they seem to exclude other groups who are also owned as property, including children (see Franklin, 1983). Yet Patterson, quoting Elkins on the American caricature of the slave, Sambo, illustrates the fetishized version of the child at work in constructions of Black beings: 
Sambo, the typical plantation slave, was docile but irresponsible, loyal but lazy, humble but chronically given to lying and stealing; his behavior was full of infantile silliness and his talk inflated with childish exaggeration. His relationships with his master was one of utter dependence and childlike attachment: it was indeed this childlike quality that was the very key to his being. (p. 82)

Sambo reflects "a perfect description of the dishonoured condition" (p. 96), according to Patterson, who also acknowledges that social life is not impossible for Black peoples but, rather, contingent on the masters' validation. Slaves may indeed enjoy honor and sociality but they do so at the discretion of the master as one must in a state of childhood. Indeed, the inability of a slave to make a legitimate claim of birth, paired with the right of the master to recognize or refuse to recognize a slave's status or identity, is a direct reflection of the misopedic relation between fully human adults and subhuman children. The capacity to issue a claim of birth or honor, like political consent, was privileged during the Enlightenment as the fundamental marker of freedom, not by chance but precisely because it is a capacity absent in young children and therefore deniable to those categorized as children. Thus, insofar as a child does enjoy honor or social connection, it is within the ideology of adulthood (Nandy, 1984) and at the behest of laws created by a community of White adults to guarantee a postion of privilege for White adults. In the figure of the child, we locate the originary moment in which the subaltern quite literally cannot speak, to invoke Spivak's vital intervention. This suggests that the idea of "natal alienation" is redundant because, according to the Western idiom of naturally degraded natality, to be newly born is to exist in the sub-human state over which adults claim authority and against which adults define themselves. Natality is always, in this sense, birth into alienation.

There have been black thinkers have explored the modern racial order and its misopedic structure, most notably the scholar responsible for coining the term "micro-aggression," Dr. Chester Pierce, who used the term to denote the everyday forms of degradation and insult experienced by Black peoples. Children, too, are subjected to relentless micro-aggressions, Pierce and Allen (1975) argued in an article on "childism," a term Pierce coined to refer to societal prejudice against children. Few have stated the case as clearly as Pierce has, writing that insofar as successive generations of children are socialized through direct experience of subordination into a vision of humanity segregated between older and younger, such experiences stand as a virtually ubiquitous foundation for a vision of humanity subsequently divided by race as well as gender: 
We contend that childism is the basic form of oppression in our society and underlies all alienation and violence, for it teaches everyone how to be an oppressor and makes them focus on the exercise of raw power rather than on volitional humaneness. The object of this article is to emphasize the ubiquity of childism, in the hope that with increased awareness it can be minimized, forlike its derivatives, sexism and racism - it is found in virtually everyone. (p. 266)

The figure of the degraded child is also central, though less explicitly, in the work of theorists such as C. W. Mills (1999), who examines how racial hierarchy informs the social contract tradition upon which contemporary liberal democracy is partially founded. Mills shows how liberal ideas emerged in the context of colonialism when it became necessary to see European domination as a benefit to "nonwhite natives who are deemed childlike, incapable of self-rule and handling their own affairs, and thus appropriately wards of the state" rather than consenting parties to a social contract (p. 13). The racial contract predefines who possesses the form of agency required to contribute to a political community, which had the effect of reinforcing "the tendency of whites to regard Black people as childlike and dependent, even when they were nominally free" (p. 39). ${ }^{1}$ Mills followed previous thinkers in arguing that slavery has been historically ubiquitous but "acquired a color" in the medieval period (p. 57), which, as argued above, was the historical process by which the idea of natural slavery based on age shifted to an idea of natural slavery based on race. Likewise, with respect to Wynter's (1995) observation that the early modern world generated an "otherness based on race" (p. 42), we see the racial construction of childhood that positioned immature Blackness as ontologically subordinate to mature Whiteness. ${ }^{2}$

\section{Whiteness as Adulthood and the Presumption of Innocence}

It is rather uncontroversial to claim that children occupied a degraded position in the contexts of early-modern Europe and America. The claim that childhood remains a degraded position today is much more contested. Contemporary cultural scripts tend to depict childhood in terms of the child's inherent freedom to explore, spaces of security, and leniency with respect to childhood foibles. Such an optimistic narrative, while not wholly ungrounded, is nevertheless reflective of a popular but erroneous mythos of protective childhood innocence.

The generic ascription of innocence to the domain of childhood is a complicated issue, in large part due to the conflation of numerous distinct notions of innocence (e.g., epistemic, carnal, legal), each with its own particular implications. Most accounts of protected childhood tend to confuse these 
distinct ideas of innocence, which is significant because very few ideals of innocence are, in fact, protective. The attribution of epistemic innocence (i.e., the lack of worldly experience and knowledge) was, for instance, a pretense for the colonial assimilation of Indigenous youth via forced attendance in genocidal residential school systems. Likewise, the cultural esthetic of sexual innocence, cultivated during the Romantic and Victorian periods by artists and intellectuals, was often rooted in the erotic fetishization of youthful purity and its corollary provocations to both protect and violate. Like Christian sins of sexual vice and promiscuity, the ideal of childhood innocence constituted a objectification of youth sexuality (an expression of misopedy that also informs misogyny).

The political uses of childhood innocence in the cultivation of a racial order have been comprehensively explored by Robin Bernstein (2011). Bernstein shows how American White supremacy is reinforced through the exclusive attribution of innocence and the capacity to suffer to White girls. Whereas the pure, tender, and innocent White girl is "deserving of protection," Black girls are effectively insensate and "disqualified from all those qualities" (p. 29). Childhood is depicted in art, literature, and popular culture as a form of vulnerability embodied in feminine youth, an innocence that invites sympathy and protection. Cultural artifacts mark out Black girlhood in contradistinction "by the inability to feel or to suffer" which functionally precludes Black youth from claiming the protections of childhood (p. 20). The antebellum demarcation of White childhood innocence from corrupted Black childhood is said to structure the contemporary treatment of Black girls as less innocent than White girls (see Goff, Jackson, Di Leone, Culotta, \& DiTomasso, 2014).

Yet notions of innocence (and sexual innocence in particular) are paradoxical in that they serve as the impetus behind both the protection and the exploitation of children. The 18th-century Romantic construction of childhood began in many respects as an objectification of sexual purity and a fetishization of the pain and suffering that accompanies its violation. As historian Larry Wolff (2013) has shown, the "cultural construction of childhood's innocence made it possible to imagine the violation of that innocence," and so it is no coincidence that the so-called discovery of childhood innocence was accompanied by the explosion of child pornography in popular culture (p. 88). Romantic intellectuals such as J. J. Rousseau were unapologetic about their desirous fascinations. In his Confessions, Rousseau described how he and a friend purchased an 11-year-old Italian girl, Anzoletta, from her family with the intention of cultivating her into a sex-slave. Anzoletta's innocence presented Rousseau with both an alluring mystery as well as assurance that she was uninfected with venereal diseases. Anzoletta was spared in the end, 
however, for in the process of cultivating a Platonic relationship with the girl (what Rousseau referred to as the "sowing before the harvesting") her captors grew more interested in contemplating Anzoletta's provocative innocence from a distance than following through with their original intentions.

Most children in Anzoletta's position were not so fortunate. Romantic thinkers seemed to have found the pain and suffering of sexual violation to be one of the most captivating features of childhood purity. Wolff provides an exemplary instance in Denis Diderot's musings over a painting of a prepubescent girl mourning a dead bird. Contemplating the image of the young girl, Diderot exclaims "Delicious! Delicious!" and proceeds to reimagine the girl's pain and suffering as having resulted from being abandoned by her adult lover, to which he adds, "I wouldn't be too displeased to have been the cause of her pain" (p. 86). The pedophillic exploits of deSade and Casanova depicted in 18th-century literature echoed a similar captivating relationship between innocence and violation. In Mozart's famous opera, Don Giovanni, the title character is boasted to have had sexual relations with numerous "la piccina" (p. 87), or "little ones," the semantic and conceptual European precursor to the racialized and sexualized "pickaninny" of 19th-century America. Beginning in the Romantic period, the esthetics of sexual virtue and vice emerged as corollary objectifications of childhood, neither of which could be characterized in terms of promoting childhood freedom, security, or leniency.

Whatever allegedly protective status the sexual innocence of children was supposed to have granted has proven historically ineffective. It would be centuries before laws would be passed to safeguard children from molestation, laws which fail today to protect Black girls who are deemed less innocent (Epstein, Blake, \& Gonzalez, 2017; Ocen, 2015). These laws tend to position youth as passive objects, reified by the ideal of innocence. Early child protection records in the United States revealed that child sexual abuse was a widespread norm. One study of New York court documents between 1886 and 1955 found that in more than $80 \%$ of reported cases of sexual assault, the victim was a child (Robertson, 1992, p. 2). All races were represented, though almost all cases involved families in the working class. As another study put it, "In contrast to artistic images about the purity and innocence of children, at the turn of the century child protection agencies were well aware that incest and sexual abuse were prevalent among the poor" (Wasserman \& Rosenfeld, 1992, p. 56). It is reasonable to presume, however, that the prevalence of sexual assault was no less significant among wealthy families and that legal systems simply offered greater protection for those who occupied higher (predominantly White) socio-economic positions. In practice, the protected status of sexual innocence was ambivalent at best. For at the same time as the rhetoric of purity was deployed in the call for stricter laws to protect White 
girls from sexual slavery, the very same ideals of sexual purity were being utilized to auction off their virginity to the highest bidder, always ignoring the plight of Black girls who were conceptualized as sexually corrupted.

Thus, a major complication in the view that the violence enacted on Black youth is the result of a failure to extend the protections of childhood is the ahistorical nature of protected childhood itself. Irrespective of the earlymodern shift toward an esthetic of blissful and bucolic childhood found in art and literature, actual childhood has yet to be a space of refuge or protection. By the 1970s, although almost every developed nation-state had abolished corporal punishment in prisons, declaring that the practice was dehumanizing and had no merit as a corrective, virtually all of these jurisdictions preserved legal sanctions allowing parental and educational violence against children. More than $80 \%$ of children experience violence in the home (Grogan-Kaylor \& Otis, 2008; Lansford \& Dodge, 2008; Zolotor, Theodore, Runyan, Chang, \& Laskey, 2011). It is estimated that more than 6 million children are abused every year (U.S. Department of Health and Human Services, 2014). Not unrelated to these dim statistics is the fact that suicide is the third leading cause of death for children above the age of 10 . For children 15 and older, suicide is the second most prevalent cause of death, homicide is the third (Centers for Disease Control and Prevention [CDC] \& National Center for Injury Prevention and Control, 2012). Indeed, a U.S. congressional report (Government Accountability Office, 2011) suggests that more than 2,400 children are killed by their parents or caregivers every year, roughly six children every day. Scholars must be cautious when presenting popular narratives of modern protective innocence as if they reflected the empirically realities of childhood experience.

The only relation between childhood and innocence that has reliably spared youth from the violence endemic to childhood has been the conceptual relocation of youth out of the category of corrupt and criminal childhood to the category of adulthood. Historically, positioning youth as proto-adults or quasi-adults has been accomplished by formally and informally expanding the legal presumption of innocence enjoyed by White adults to include White youth. It is instructive, perhaps, that the term "innocence" itself derives etymologically from the Latin inocere denoting the absence of harm and culpability as opposed to the absence of wisdom or sexual experience. The term innocence carries a juridical sense of presumed innocence as captured in the Roman legal principle of "innocent until proven guilty" (Ei incumbit probatio qui dicit, non qui negat). It is this form of innocence - the innocence of the White adult - that is denied to black people, especially black youth.

By the 16th century, upper-class White children enjoyed protections from assault that were comparable with those enjoyed by adults, though 
protection from parents and tutors was uncommon (Brewer, 2007, p. 155). Initially, poor White youth did not fare much better than peoples associated with the "child races." 3 Eventually, however, White society sought more systematic ways of disassociating youth of European descent, irrespective of class, from slaves. Intellectual, legal, and political distinctions began to emerge that functionally distinguished youth in the White race from the "child races" in everything from education to criminal law. White youth were increasingly re-conceptualized as benefiting from White civilization, as already progressing toward adulthood, as "young adults" in their teenage years, and as proto-citizens who make mistakes but are nevertheless capable of consenting to systems of governance or taking up some of the responsibilities designated to adults.

In the United States, the institutional pattern of re-categorizing White youth as quasi-adults closely followed the evolution of the child welfare system. The earliest form of protection for children in the United States were almshouses which were typically churches or private homes where White children were warehoused and deployed as indentured servants. After the Civil War, however, the emancipation of Black children from slavery seemed to situate these indentured White children in an even more degraded position than newly freed Black children:

When in fact children of African descent were no longer being bought and sold, discomfort arose in the child welfare movement with the fact that children of European descent were still being sent into a state of serfdom through indenture. The first children to benefit from this discomfort were almost exclusively white. (Billingsley \& Giovannoni, 1972, p. 34)

For a young Black boy, the child welfare system upon which he would come to depend upon being freed from slavery was "originally designed with his deliberate exclusion at its very core" (p. 33). As Frederick Douglass noted, White children were understood as already advancing toward adulthood in a way that Black children could not.

Black youth remained designated as perpetual children. As such, they were much more likely to be abandoned by the system as juvenile "delinquents" while poor White children were included with White adults as mere "dependants." As Billingsley and Giavannoni (1972) remark, "An unspoken value system had been established in relation to the provision of children's services: no white children shall be worse off than any Black child; no Black child shall be any better off than any white child" (p. 24). After the American Civil War, White society began the process of removing White youth from institutions bearing an association with servitude or slavery. Reforms were 
enacted in child labor law to ensure that Blacks could not take paying jobs away from young White workers (Sundue, 2009). Such reforms were explicitly aimed at keeping "white children from lagging behind their 'coloured' counterparts" (Schmidt, 2010, p. 60). Reforms designed to strengthen racial segregation in schools began in the antebellum era (Melish, 1998, p. 61), relegating Black youth to substandard education while White students attended relatively well-funded schools where they ushered into citizenship and its many opportunities (Moss, 2009, p. 192). In the domain of policing and jurisprudence, White youth were less likely to be viewed as inherently criminal while Black youth continued to be judged according to a model of criminal immaturity. By the early 20th century, the presumption of innocence was more or less exclusively "the province of white children" (Grant, 2014, p. 154). Today, White youth in contemporary state institutions benefit not from an esthetics of sexual innocence but from a legacy of ever-expanding protective adult privileges that are denied to Black peoples.

\section{Conclusion: The Color of Childhood}

More research is needed on the historical and contemporary extrication of White youth from the degraded category of childhood. I would like to conclude by suggesting that understanding and confronting the modern racial order requires a sustained critical intervention into the misopedic order that subtends it. This will require a major reorientation in emancipatory and abolitionist research since thinkers risk reincribing racial logics when centering adult capacities as a necessary qualification of inclusion into the caetgory of fully human, perpetuating the ontological misfortune that positions the child as the unfree and unthought Other of a humanistic society. As Maria Kromidas (2014) describes it, "Humanism, with its discourse of progress and perfectibility theorized as a movement out of nature, no longer holds the racial Other or prehistoric man as the representative of ground zero- that position is now solely the child's" (p. 429). One consequence of neglecting the centrality of the degraded child in systems of domination, as Corinne T. Field (2014) has argued, is that we overlook how "white male maturation" became "the fundamental distinction between those capable of governing themselves and those naturally subject to the will of others, both in households and in the state" (p. 12). Without a robust understanding of how childhood grounds modern logics of domination, emancipatory movements will likely reinforce those logics.

White feminists in the late-19th century, for example, protested the infantilization of marginalized groups while continuing, as Field observes, "to promote disparate measures of maturity and to infantilize each other" (p. 157). 
Attempts to reject the designation of immaturity simply affirmed the logic of development: "White women's assertion of their own maturity had long depended upon a contrast with other adults who remained more childlike" (p. 171). A politics of resistance that predicates full humanity on becoming a speaking subject - that is, a subject of education, literacy, sophistication, civilized nature, artistic acumen, independence, maturity, or civilized rational modernity - will recapitulate the violence that configures the human in opposition to the young, peoples with disabilities, and anyone who is otherwise associated with emotion, spontaneity, and resistance to authority. Fanon (2008a) reminds us of the folly of appealing to intellectual capacities as a criterion of full humanity:

When someone else strives and strains to prove to me that black men are as intelligent as white men, I say that intelligence has never saved anyone; and that is true, for, if philosophy and intelligence are invoked to proclaim the equality of men, they have also been employed to justify the extermination of men. (p. 135)

In a racial order predicated on the designation of childhood as a site of naturalized criminality, violence, and servitude, to which black peoples are principally relegated, not only will appealing to the category of childhood fail to protect black youth it will reaffirm an antiquated and pernicious misopedic distinction between human beings. Returning to Kipling's depiction of nonEuropean peoples as half-devil and half-child, we can note something of a tautology: the devil was himself the first disobedient and petulant child of God. His is the mythical domain of juvenile chaos and infantile desire posed in contradistinction to the order, reason, and piety demanded by a Heavenly Father; the same order of parental authority and dedication to paternal law for which Abraham was willing to murder his child, Isaac. To be a devil is to disobey and to disobey is to be a child. Accordingly, sinners are the children of the devil, and as such the children of a child. As one psychologist who studied child protestors during the civil rights era noted, Black youth were struggling in a context in which white society deemed them "not merely children but, as Negroes, the children of children" (Coles, 1964-1965, p. 80).

Insofar as the logics of contemporary racialization and anti-Blackness are rooted in a culture of misopedy, resistance to racism can no longer be served by the ahistorical narrative that Black children are denied the privileges of protected childhood. Although there may be short-term strategic utility in framing this issue in terms of Black youth being excluded from some idealized vision of protected childhood, the difficulty for modern emancipatory struggles will be finding a way to abjure the misopedic grammar of race and colonialism altogether. 


\section{Declaration of Conflicting Interests}

The author declared no potential conflicts of interest with respect to the research, authorship, and/or publication of this article.

\section{Funding}

The author received no financial support for the research, authorship, and/or publication of this article.

\section{Notes}

1. Stacy Clifford Simplican (2015) has argued persuasively that modernity is structured by a more fundamental "capacity contract" designed to exclude those with disabilities who do not meet standards of rationality.

2. Indigenous peoples of Africa were not the only peoples to be conceptualized under the rubric of the "child races." Indigenous peoples of North America were also considered an exemplar of allegedly immature civilization (Rollo, 2018). It is for this reason, as Elizabeth Gagen (2007) writes, that in the modern development of racial hierarchy "childhood emerged as universally inferior, regardless of race" (p. 16).

3. Indeed, poor children were among the first upon whom the settler colonial project in the New World would be built. As Painter (2010) informs us, "A first shipment of 100 homeless children landed in Virginia around Easter in 1619, some four months before the arrival of ' 20 and odd Negroes' became the symbolic ancestry of African Americans. And so it went, with Africans and Britons, both ostensibly indentured servants, living under complete control of their masters, subject to sale as chattel at any time" (p. 41).

\section{References}

Bernstein, R. (2011). Racial innocence: Performing American childhood from slavery to civil rights. New York: New York University Press.

Billingsley, A., \& Giovannoni, J. (1972). Children of the storm: Black children and American child welfare. New York, NY: Harcourt, Brace and Jovanovich.

Brewer, H. (2007). By birth or consent: Children, law, and the Anglo-American revolution in authority. Chapel Hill: University of North Carolina Press.

Bunge, M., Frethiem, T. E., \& Gaventa, B. R. (Eds.). (2008). The child in the Bible. Grand Rapids, MI: Wm. B. Eerdmans.

Centers for Disease Control and Prevention \& National Center for Injury Prevention and Control. (2012). 10 leading causes of death by age group, United States-2012. Retrieved from http://www.cdc.gov/injury/wisqars/pdf/leading causes_of_death_by_age_group_2012-a.pdf

Clifford Simplican, S. (2015). The capacity contract: Intellectual disability and the question of citizenship. Minneapolis: University of Minnesota Press. 
Coles, R. (1964-1965). Children and racial demonstrations. The American Scholar, $34,78-92$.

Cooper, K. (2007). The fall of the Roman household. Cambridge, UK: Cambridge University Press.

Drayton, W. (1836). The south vindicated from the treason and fanaticism of the northern abolitionists. Philadelphia, PA: H. Manly.

Duane, A. M. (2017). Introduction: When is a child a slave? In A. M. Duane (Ed.), Child slavery before and after emancipation: An argument for child-centered slavery studies (pp. 1-22). Cambridge, UK: Cambridge University Press.

Epstein, R., Blake, J. J., \& Gonzalez, T. (2017). Girlhood interrupted: The erasure of Black girls' childhood. Washington, DC: Georgetown Law Center.

Fanon, F. (2008a). Black skin, White masks (R. Philcox, Trans.). New York, NY: Grove Press. (Original work published 1952)

Fanon, F. (2008b). The wretched of the earth (R. Philcox, Trans.). New York, NY: Grove Press. (Original work published 1961)

Field, C. T. (2014). The struggle for equal adulthood: Gender, race, age, and the fight for citizenship in antebellum America. Chapel Hill: University of North Carolina Press.

Franklin, V. P. (1983). Review of slavery and social death, by Orlando Patterson. The Journal of Negro History, 68, 212-216.

Frazier, E. F. (1962). A controversial question: Do American Negroes have what Africa needs? Black World/Negro Digest, 12, 62-74.

Gagen, E. (2007). Reflections of primitivism: Development, progress and civilization in imperial America. Children's Geographies, 5, 15-28.

Gardner, J. (1998). Family and familia in Roman law and life. Oxford, UK: Oxford University Press.

Goff, P. A., Jackson, M. C., Di Leone, B. A. L., Culotta, C. M., \& DiTomasso, N. A. (2014). The essence of innocence: Consequences of dehumanizing Black children. Journal of Personality and Social Psychology, 106, 526-545.

Gordon, L. R. (1997). Her majesty's other children: Sketches of racism from a neocolonial age. Lanham, MD: Rowan \& Littlefield.

Government Accountability Office. (2011). Child maltreatment: Strengthening national data of child fatalities could aid in prevention (Report to the Chairman). Washington, DC: Committee of Ways and Means, House of Representatives. Retrieved from http://www.gao.gov/products/GAO-11-599

Grant, J. (2014). The boy problem: Educating boys in urban America, 1870-1970. Baltimore, MD: Johns Hopkins University Press.

Grogan-Kaylor, A., \& Otis, M. D. (2008). The predictors of parental use of corporal punishment. Family Relations, 56, 80-91.

Hall, G. S. (1904). Adolescence: Its psychology and its relations to physiology, anthropology, sociology, sex, crime, and religion (Vol. 2). New York, NY: D. Appleton.

Hartman, S. V. (1997). Scenes of subjections: Terror, slavery and self-making in the nineteenth century America. Oxford, UK: Oxford University Press. 
Hartman, S. V. (2016). The belly of the world: A note on Black women's labors. Souls: A Critical Journal of Black Politics, Culture, and Society, 18, 166-173.

Hartman, S. V., \& Wilderson, F. B., III. (2003). The position of the unthought. Qui Parle, 13, 183-201.

Holden, W. C. (1855). History of the colony of Natal, South Africa. London, England: A. Heylin.

Jacobs, M. D. (2009). White mother to dark race: Settler colonialism, maternalism, and the removal of indigenous children in the America West and Australia, 18801940. Lincoln: University of Nebraska Press.

Kromidas, M. (2014). The "savage" child and the nature of race: Posthuman interventions from New York City. Anthropological Theory, 14, 422-441.

Laes, C. (2006). Children in the Roman empire: Outsiders within. Cambridge, UK: Cambridge University Press.

Lansford, J. E., \& Dodge, K. A. (2008). Cultural norms for adult corporal punishment of children and societal rates of endorsement and use of violence. Parenting: Science and Practice, 8, 257-270.

Lombroso, C. (1895). Criminal anthropology applied to pedagogy. The Monist, 6, 50-59.

Lorde, A. (1984). Eye to eye. In Sister outsider: Essays and speeches. New York, NY: Random House (pp. 145-175).

Magubane, B. M. (1996). The making of a racist state: British imperialism and the Union of South Africa, 1875-1910. Trenton, NJ: Africa World Press.

McClintock, A. (1995). Imperial leather: Race, gender, and sexuality in the colonial contest. New York, NY: Routledge.

McCord, C.H. (1914). The American Negro as Dependent, Defective and Delinquent. Nashville, TN: Press of Benson Printing Company.

Melish, J. P. (1998). Disowning slavery: Gradual emancipation and race in New England, 1780-1860. Ithaca, NY: Cornell University Press.

Mill, J. S. (1989). On liberty and other writings (S. Collini, Ed.). Cambridge, UK: Cambridge University Press. (Original work published 1859)

Mills, C. W. (1999). The racial contract. Ithaca, NY: Cornell University Press.

Moss, H. J. (2009). Schooling citizens: The struggle for African American education in antebellum America. Chicago, IL: The University of Chicago Press.

Mousourakis, G. (2012). Fundamentals of Roman private law. New York, NY: Springer.

Nandy, A. (1984). Reconstructing childhood: A critique of the ideology of adulthood. Alternatives: Global, Local, Political, 10, 359-375.

Ocen, P. (2015). (E)Racing childhood: Examining the racialized construction of childhood and innocence in the treatment of sexually exploited minors. UCLA Law Review, 62, 1586.

Ozment, S. (1983). When fathers ruled: Family life in reformation Europe. Cambridge, MA: Harvard University Press.

Painter, N. I. (2010). The history of White people. New York, NY: W.W. Norton.

Parkman, F. (1994). The conspiracy of Pontiac and the Indian war after the conquest of Canada. Lincoln: University of Nebraska. (Original work published 1851) 
Patterson, O. (1982). Slavery and social death: A comparative study. Cambridge, MA: Harvard University Press.

Pierce, C., \& Allen, G. (1975). Childism. Psychiatric Annals, 5, 266-270.

Reade, W. W. (1872). The martyrdom of man. New York, NY: A. K. Butts \& Co. Kiernan.

Robertson, S. (1992). Crimes Agaist Children: Sexual Violence and Legal Culture in New York City, 1880-1960. Chapel Hil, NC: University of North Carolina Press.

Rollo, T. (2018). Feral children: Settler colonialism, progress, and the figure of the child. Settler Colonial Studies, 8, 60-79.

Schmidt, J. D. (2010). Industrial violence and the legal origins of child labor. Cambridge, UK: Cambridge University Press.

Schweitzer, A. (1931). The primeval forest. Baltimore, MD: Johns Hopkins University Press.

Sexton, J. (2010). People-of-color-blindness: Notes on the afterlife of slavery. Social Text, 28(2), 31-56.

Sexton, J. (2011). The social life of social death: On Afro-pessimism and Black optimism. Intensions, 5, 1-47.

Sexton, J. (2015). Unbearable blackness. Cultural Critique, 90, 159-178.

Spillers, H. J. (1987). Mama's baby, papa's maybe: An American grammar book. Diacritics, 17, 64-81.

Sundue, S. B. (2009). Industrious in their station: Young people at work in urban America, 1720-1810. Charlottesville: University of Virginia Press.

U.S. Department of Health and Human Services. (2014). Administration on children, youth and families: Child maltreatment 2013. Washington, DC: U.S. Government Printing Office.

Van Evrie, J. H. (1853). Negroes and negro slavery: The first an inferior race-The latter its normal condition. Baltimore, MD: John D. Toy.

Wasserman, S., \& Rosenfeld, A. (1992). An overview of the history of child sexual abuse and Sigmund Freud's contribution. In W. O'Donahue \& J. H. Greer (Eds.), The sexual abuse of children, Vol. I: Theory and research. New York, NY: Routledge (pp. 49-72).

Winston, G. T. (1901). The relation of the Whites to the Negroes. The ANNALS of the American Academy of Political and Social Science, 18, 105-118.

Wolff, L. (2013). The child in the enlightenment: The complications of innocence. In P. S. Fass (Ed.), The Routledge history of childhood in the western world (pp. 78-100). New York, NY: Routledge.

Woodhouse, B. B. (2008). Hidden in plain sight: The tragedy of children's rights from Ben Franklin to Lionel Tate. Princeton, NJ: Princeton University Press.

Wynter, S. (1995). 1492: A new world view. In V. Hyatt \& R. Nettleford (Eds.), Race, discourse, and the origin of the Americas: A new world view (pp. 1-57). Washington, DC: Smithsonian Institute Press.

Wynter, S. (2003). Unsettling the coloniality of being/power/truth/freedom: Towards the human, after man, its overrepresentation: An argument. CR: The New Centennial Review, 3, 257-333. 
Zolotor, A. J., Theodore, A. D., Runyan, D. K., Chang, J. J., \& Laskey, A. L. (2011). Corporal punishment and physical abuse: Population-based trends for three-to11-year-old children in the United States. Child Abuse Review, 20, 57-66.

\section{Author Biography}

Toby Rollo holds a $\mathrm{PhD}$ in political science from the University of Toronto and is currently a Postdoctoral Fellow with the Social Sciences and Humanities Research Council in the Department of Political Science at the University of British Columbia. 